\title{
ЈЕЗИК КАО ПРЕПРЕКА ТАКТИЧКОЈ ЕФЕКТИВНОСТИ АУСТРОУГАРСКЕ ВОЈСКЕ У ПРВОМ СВЕТСКОМ РАТУ*
}

\author{
Михајло Копања**, истраживач-приправник \\ Институт за међународну политику и привреду, Београд
}

\footnotetext{
* Рад представља део научног пројекта „Србија у савременим међународним односима: Стратешки правци развоја и учвршћивање положаја Србије у међународним интегративним процесима спољнополитички, међународни економски, правни и безбедносни аспекти“, који финансира Министарство просвете, науке и технолошког развоја Републике Србије (бр. 179029), а реализује Институт за међународну политику и привреду, у периоду од 2011. до 2019.

** mihajlo.kopanja@diplomacy.bg.ac.rs
} 



\section{ЈЕЗИК КАО ПРЕПРЕКА ТАКТИЧКОЈ ЕФЕКТИВНОСТИ АУСТРОУГАРСКЕ ВОЈСКЕ У ПРВОМ СВЕТСКОМ РАТУ}

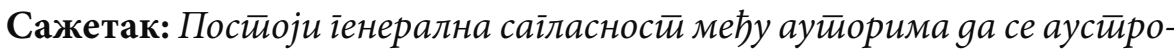
уіарска војска у Првом светиском райу йоказала далеко исйоg оноїа шиио јој је юен војни йоиенцијал омоіућавао, а амбииије захиевале. Међу-

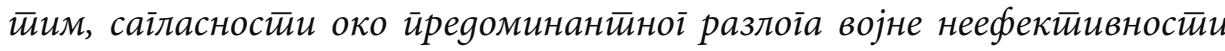
аустироуіарске војске нема. Цит овоі раgа јестие gа йреgстиави алитерна-

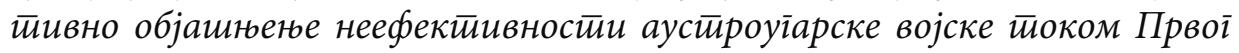

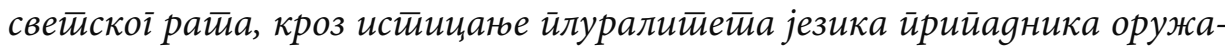

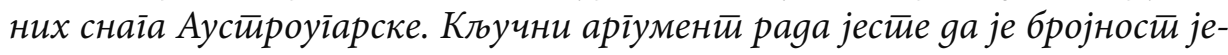
зика којима су се служили иррийаgници ауситроуіарске војске онемоіућила аgекватину комуникацију и координацију између војника и официра, али и између војника различитих националностии, иичме онемоіућавајући

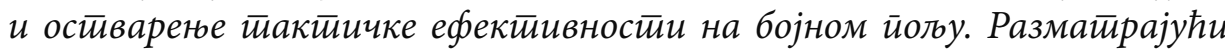

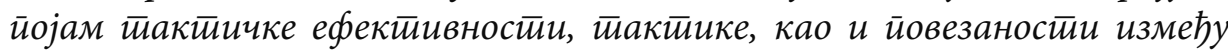

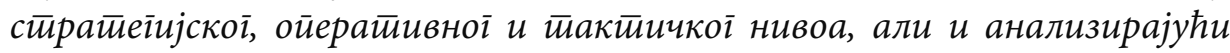
Аустироуіарску и юену војску уочи Првоі светискоі райа, раg йоказује gа се комитексна језичка иолитиика аусирооиіарске војске йоказала неу-

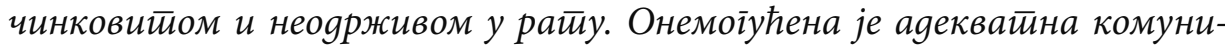

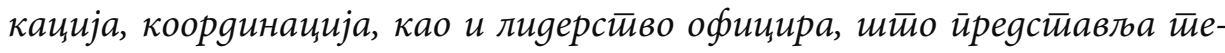

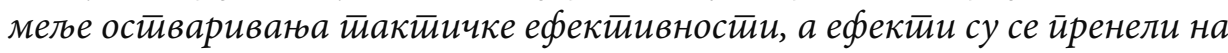
остиале нивое и довели gо йораза Аустироуїарске.

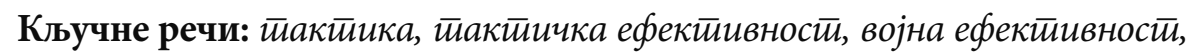
језик, Аустироуїарска. 


\section{Увод}

Уочи Првог светског рата, Аустроугарска је представљала једну од великих сила које су чиниле „Концерт Европе“. Иако несумњиво најслабија од свих европских сила тог времена, Аустроугарска је била далеко од безначајног актера у међународној политици (Kennedy, 1988: 163, 215-219). Са значајним територијалним, економским и демографским потенцијалима, који представљају основу војног потенцијала, могла је да се пореди са осталим значајним државама тог времена. Не рачунајући Русију, Аустроугарска је била територијално највећа држава и друга по популацији у Европи (Romsics, 2002: 1). Међутим, како Пол Кенеди (Paul Kennedy) наводи, „војни потенцијал ... није исто што и војна моћ“ (Kennedy, 1988: 198), и Аустроугарска још од врхунца своје моћи у 16. и 17. веку (Kennedy, 1988: 31-71) није успела да преведе војни потенцијал у војну моћ. У деценијама релативног мира у Европи након уједињења Немачке и Италије, овај недостатак био је у другом плану. Међутим, избијањем Првог светског рата сав недостатак војне моћи Аустроугарске изашао је на видело и у крајњој линији се може аргументовати да ју је коштао опстанка у међународној арени.

Случај неефективности аустроугарске војске током Првог светског рата није прошао неопажено у академској литератури и током година представљена су бројна објашњења разлога неефективности аустроугарске војске. Махом од интереса војним историчарима, ови радови несумњиво дају обиље материјала од користи за истраживања, међутим из перспективе наука безбедности и политичких наука то делом представља и отежавајућу околност. Приступ политиколога заинтересованог за историју и приступ историчара заинтересованог за политику имају своје различите нијансе (Strachan, 2019: 171-172; Murray and Millett, 2010: XI-XII). Историчар настоји да прикаже ширу слику и ретко наглашава јасну каузалну логику где се кључно објашњење може утврдити без значајније анализе самог рада.

У постојећој литератури која анализира неефективност аустроугарске војске предоминантна су следећа објашњења фактора који су до тога довели: нелојалност припадника аустроугарске војске који етнички нису били Немци или Мађари, неадекватна опремљеност, неадекватна стратегија, парламентарно спутавање и неадекватно финансирање (Dredger, 2017: 1-9). Међутим, најзаступљеније међу њима свакако је објашњење да је нелојалност бројних етничких група које су сачињавале популацију Аустроугарске довело до неефективности њене војске. Једноставно речено, аустроугарска војска је била неефективна, јер знатан део њених припад- 
ника, који нису били етнички Немци или Мађари, није желео да се бори. Ово објашњење присутно је још у радовима који су објављени током Првог светског рата (Trevelyan, 1915: 862; Цвијић, 1996: 261), међутим, новија истраживања га оповргавају, објашњавајући да представља производ предрасуда политичке елите у Бечу о етничким мањинама, као и страха да ће доћи до побуне припадника етничких мањина. Аутори наводе да је уочи Првог светског рата мобилизација војске спроведена без потешкоћа у свим деловима монархије (Павловић, 2018: 285; Rothenberg, 1989: 132), и да је током рата постојао осећај лојалности, храбрости и спремности за борбу међу припадницима аустроугарске војске (Schindler, 2003; 2015; Dredger, 2017; Cornwall, 1997; Lein, 2009; Herwig, 2009).

Наведена објашњења фактора који су довели до неефективности аустроугарске војске не треба схватати на начин да један апсолутно искључује утицаје других. Фокусирање радова на одређено објашњење подразумева да је тај фактор имао предоминантну улогу, док су остали имали делимичан и споредни утицај. Пратећи такав приступ, овај рад пружа алтернативно објашњење предоминантног разлога неефективности аустроугарске војске, стављајући у први план и истичући утицај језичке баријере међу њеним припадницима. Постојање разлика у језику онемогућило је ефективно спровођење војних операција током Првог светског рата. Иако помињана у литератури (Rothenberg, 1998; Schindler, 2015; Engle, 2014; Kardum and Korea Gajski, 2012), језичка баријера није идентификована као примарни разлог који је утицао на неефективност и у крајњој линији пораз аустроугарске војске у Првом светском рату.

С обзиром да рат представља колективни друштвени подухват који захтева залагање и заједничко деловање великог броја људи, способност комуникације између припадника оружаних снага представља основу ефективности оружаних снага и остварења ратних циљева. У овом случају, под способношћу комуникације се не мисли на системе веза и технологију која је омогућила замену једног Филипида или голуба писмоноше радио-везом, већ на базични смисао комуникације, то јест преношење мисли и значења између појединаца и група. Предуслов сваког заједничког деловања људи јесте разумевање шта треба урадити, како треба урадити и који појединац ће који део урадити. У савременом рату појединац не може сам донети победу, чак и уколико разуме ситуацију у којој се нашао и зна шта треба чинити, већ своје мисли мора поделити са другима, да би се кроз заједничко деловање успешно извршио тактички задатак (Marshall, 2000: 132-137). Нагли развој средстава комуницирања довео је до потпуног запостављања базичног смисла комуникације као говора између припадника јединице и поред тога што успешност остварења тактичког задатка почива на неопходности међусобног разговора (Marshall, 2000: 136-137). 
У случају аустроугарске војске, питање језичке баријере као препреке ефективности је израженије и кључно на тактичком нивоу, из разлога што је, с једне стране аустроугарска војска била изразито етнички хетерогена, док је са друге стране официрски и подофицирски кор био сачињен готово апсолутно од Немаца и Мађара. Поред тога, тактички, оперативни и стратегијски нивои оружаних сукоба су међуповезани и тактика као најнижи ниво служи остварењу оперативног и стратегијског нивоа, као и политичких циљева због којих се ушло у рат (Betts, 2000: 6). Уколико се задаци на тактичком нивоу не могу ефективно остварити, то ће довести до пропасти остварења војних циљева и на оперативном и стратегијском нивоу (Betts, 2000: 6-7). Отуда је кључни аргумент овог рада да је до пораза Аустроугарске у Првом светском рату довела тактичка неефективност њених оружаних снага, изазвана немогућношћу комуникације између њених припадника услед разлика у језику.

\section{Тактика и тактичка ефективност}

Еволуција оружаних сукоба током деветнаестог века, у смислу технолошког развоја војне опреме, оперативног увођења артиљерије, повећања броја војника који учествују у војним операцијама, довела је до усложњавања процедура, одлука али и броја бојишта и условила потребу за бољом координацијом подухвата зарад остварења ратних циљева. Наведена потреба манифестовала се у својеврсној подели војних операција на три нивоа: стратегијски, оперативни и тактички. Иако се још од Сун Цуа (Сун Цу, 2015) правила дистинкција између стратегије и тактике, коју је додатно учврстио Клаузевиц (Carl von Clausewitz) (Clausewitz, 2007), оперативни ниво је у употребу ушао релативно касно, управо под утицајима тактичких „пат-позиција“ Првог светског рата (Luttwak, 1980-1981: 61-62; Strachan, 2008: 429), зарад прављења везе између стратегијских циљева и тактичких могућности (Бофр, 1968: 32).

За Клаузевица дистинкција између тактике и стратегије се огледа у томе да „тактика учи о употреби оружане силе у ангажовању (engagement)... [док је]...стратегија употреба ангажовања за циљеве рата“ (Clausewitz, 2007: 74). Док се стратегија бави целокупним одвијањем оружаних сукоба, тактика се бави конкретним биткама. Тиме, тактика представља својеврсну апликацију стратегије на нижој равни у конкретном времену и простору (Hart, 1991: 321). Између тактике и стратегије стоји оперативни ниво који подразумева одабир адекватних тактичких маневара кроз које се остварују стратегијски циљеви (Luttwak, 1980-1981: 61). Међутим, веза 
између стратегије, оператике и тактике није линија просте каузалности. Док је важно да се стратегијске замисли оперативно и тактички спроведу у дело, једна битка не мора нужно пресудити успешност целокупне стратегије. Термин Пирова йобеgа управо служи да се нагласи чињеница да једна добијена битка може да изгуби рат. Истовремено, једна изгубљена битка не значи да се и рат губи. Ипак, серија изгубљених битака тешко се може надокнадити стратегијским умећем.

Тактика, као апликација стратегије употребом оружане силе у конкретним сучељавањима супротстављених оружаних снага, треба бити „што прецизнија могућа наука“ (Strachan 2005: 4). Остварењем циљева на тактичком нивоу доприноси се остварењу циљева на оперативном, потом стратегијском нивоу, које се надаље преноси на циљеве које је поставила политика и због којих се приступило рату. Док се за ниво политике, стратегије и оператике у начелу може применити принцип еквифиналитета (equifinality), тактички ниво има јасан исход победе или пораза. Отуда, тактички ниво захтева већи ниво прецизности у односу на више нивое.

Међутим, зарад остварења циљева, независно од нивоа, оружане снаге држава морају поседовати не само одређени војни потенцијал, у смислу материјалних и људских ресурса, већ и степен војне ефективности (military effectiveness) (Brooks, 2007: 4). Поменуто разликовање војног потенцијала и војне моћи држава у случају Аустроугарске управо је служило наглашавању значаја војне ефективности по војну моћ и употребу војне моћи у оружаним сукобима. Штавише, сама међузависност стратегијског, оперативног и тактичког нивоа заправо представља један од кључних атрибута војне ефективности (Brooks, 2007: 10-11). Ипак, јасна дефиниција појма војне ефективности није уједначена са истраживањима социолога, војних историчара и политиколога, који из сопствене перспективе приступају и дефинишу појам (Brooks, 2007: 4-9). Поред тога, даљу забуну производи и повремена, готово наизменична употреба појмова војне ефектиивностии и војне ефикасностии. Разликовање ефикасности и ефективности не представља семантичку игру на енглеском језику, што је и видљиво у употреби оба термина и у српској литератури (Каровић и сар., 2011; Forca, 2011; Stefanović i Forca, 2005), већ имају своје разлике у значењу. Ефикасност подразумева да се ствари раде на прави начин, док ефективност подразумева да се раде праве ствари (Drucker, 2009: 32; Ковачевић и сар., 2018: 277; Jobbagy, 2009: 513). Међутим, како Алан Милет (Allan Millett), Вилијамсон Мари (Williamson Murray) и Кенет Ватман (Kenneth Watman) наводе, упркос разликовању појмова „ефективност инкорпорира одређене конотације ефикасности“ (Millet et al., 1986, 37). 
Генерално гледано, војна ефективност је способност државе да на основу материјалних и људских потенцијала генерише војну моћ (Millet et al., 1986, 37; Brooks, 2007: 9; Brathwaite, 2018: 2). Оваквом погледу треба додати и Бидлову (Stephen Biddle) одредницу произвођења повољних војних исхода (Biddle, 2017), из разлога што ефективност подразумева рађење правих ствари и што постојање војне моћи per se не значи много без разматрања о њеној примени или могућности примене. Међутим, саму војну ефективност је тешко одредити увођењем конкретних и мерљивих индикатора. Милет, Мари и Ватман исправно указују да различитост циљева, процедура и делања на стратегијском, оперативном и тактичком нивоу, упућује на неопходност одвојеног посматрања ефективности на свим нивоима (Millet et al., 1986: 38). Тек потом је могуће накнадно разматрање њихове интеграције на које упућује Риса Брукс (Brooks, 2007: 10-11). Из перспективе овог рада, тактичка ефективност је кључна и управо настоји да објасни како неадекватан степен тактичке ефективности може да доведе до свеобухватне војне неефективности.

У литератури тактичка ефективност се помиње и у алтернативном облику као борбена ефективност (combat effectiveness). Међутим, овакав термин је мање прецизан и може проузроковати забуне. На пример, у раду Филипа Хејварда (Philip Hayward) о мерењу борбене ефективности, није најјасније да ли аутор говори о тактичком или оперативном нивоу, jep се могу наћи елементи оба (Hayward, 1968). За разлику од Хејварда, Кристин Бретвајт (Kristin Brathwaite), у својој концептуалној анализи борбене ефективности, експлицитно упућује да се борбена ефективност превасходно односи на тактички ниво (Brathwaite, 2018: 2). Зарад избегавања оваквих забуна, сврсисходније и прецизније је говорити о тактичкој ефективности у складу са приступом Милета, Марија и Ватмана.

Управо рад Кристин Бретвајт представља значајан допринос разумевању тактичке ефективности. Анализирајући постојећу литературу о тактичкој ефективности, Бретвајт закључује да се истичу два кључна фактора: вешиичне војника и воља за борбу (Brathwaite, 2018: 3). Док поједини аутори стављају акценат или на вештину или на вољу, Бретвајт закључује да су оба фактора подједнако важна. Значајније, ауторка наводи и индикаторе на основу којих одређује и вештине и вољу. Индикатори вештина војника су: основна тактика, координација и комуникација и лидерство. Индикатори воље војника за борбу су: морал, дисциплина и иницијатива (Brathwaite, 2018: 3-7).

Враћајући се на циљ рада, ауторкино одређење фактора тактичке ефективности, као и њихових индикатора, указује на проблеме које језичка баријера може изазвати када је у питању тактичка ефективност. 
Индикатори координације и комуникације унутар тактичке јединице, али делом и лидерство у смислу комуникације између претпостављених подофицира и официра са војницима, почивају на чињеници да сви припадници јединице говоре истим језиком. Уколико не говоре, индикатори координације и комуникације пре свега, али и индикатор лидерства, имаће негативне вредности, утичући и на негативну вредност тактичке ефективности. Из тактичке неефективности, кроз међуповезаност нивоа организовања оружаних снага, произилази негативна вредност војне ефективности, умањујући војну моћ и онемогућавајући војсци да оствари циљеве које је поставила политика.

\section{Језичке разлике као препрека тактичкој ефективности аустроугарске војске}

Плуралитет објашњења узрока који су довели до војне неефективности и пораза Аустроугарске у Првом светском рату није без разлога. Аустроугарска је уочи Првог светског рата била држава са дванаест различитих етничких група, од којих је свака чинила макар један проценат укупне популације, две велике политичко-административне целине, привременом аустријско-мађарском економском унијом, три одвојене оружане формације, а заједничка су била само министарства спољних послова и рата, као резултат Нагодбе из 1867. године (Kardum and Korea Gajski, 2012: 352-354). Оваква ситуација омогућила је широки простор за утицај разноликих варијабли на укупно стање војне ефективности Аустроугарске у Првом светском рату. Отуда и не чуди закључак из увода да се утицаји других објашњења, поред језичке баријере, не могу апсолутно искључити.

Као што је већ напоменуто, Аустроугарска је била, не рачунајући Русију, друга по бројности популације земља у Европи. Међутим, не само да је демографски била хетерогена, са наведених дванаест већих етничких група, него није имала апсолутну етничку већину ниједне етничке групе. Релативну већину имали су Немци, који су чинили 24 процента или око дванаест милиона људи (Romsics, 2002: 1). Поред Немаца, демографска слика Аустроугарске је процентуално била следећа: Мађари 20 процената, Чеси 13 процената, Пољаци 10 процената, Украјинци и Русини 8 процената, Румуни 6,5 процената, Хрвати 5 процената, Срби 3 до 4 процента, Словаци 4 процента, Словенци 2,5 процената, Италијани 1,6 процената и Бошњаци 1 проценат (Romsics, 2002: 1-3).

Приказана хетерогеност популације додатно је била отежана географском дистрибуцијом наведених етничких група и неравномерним 
економским развојем. Иако се ови аргументи могу узети и при стављању у први план питања лојалности етничких мањина на војну ефективност, они могу бити протумачени и из језичке перспективе. Географска дистрибуција утицала је на то да поједине етничке групе нису имале готово никаквог контакта са другим групама. Помало је незамисливо да су Срби, Бошњаци и Хрвати из Босне и Херцеговине имали значајније интеракције са Италијанима из Тирола или Русинима и Украјинцима из Галиције, што би им омогућило да на основу говора препознају своје судржављане. Истовремено, ефекти неравномерног економског развоја се могу посматрати како кроз интеракције између етничких група, тако и кроз познавање додатних језика поред матерњег. Економски неразвијенији делови упућују на економију засновану на пољопривреди, у којој је становништво везано за земљу коју обраћују, што смањује могућност, али и потребу, за ширим интеракцијама ван непосредног окружења. Са друге стране, економски развијенији делови привлаче појединце из неразвијених крајева, дајући им прилику да науче додатни језик поред матерњег, доприносећи тако превазилажењу језичке баријере.

Оружане снаге Аустроугарске рефлектовале су како политичку, тако и демографску ситуацију у држави. Уместо јединствене, аустроугарска војска је била сачињена од три одвојене целине. Под контролом Аустрије била је Царско-краљевска војска (Kaiserlich-Königlich Landwehr), под контролом Мађарске Мађарска краљевска војска (Magyar Királyi Honvédség), док је заједничка војска царства била Царска и краљевска војска (Kaiserlich und Königlich Armee), која је уједно и чинила највећи сегмент аустроугарске војске (Bassett, 2016: 367). Оваква структура оружаних снага Аустроугарске је резултат компромиса између супротстављених тежњи две стране, где мађарска страна није желела заједничке оружане снаге, већ искључиво сопствену, аутономну војску, а аустријска страна није желела да дозволи одвојене оружане снаге.

По питању демографске структуре, аустроугарске оружане снаге рефлектовале су демографску слику царства без апсолутне етничке већине. Аустроугарска војска је била сачињена од десетак већих етничких група (видети табелу 1) и у апсолутним бројевима чинило ју је око два милиона људи (Strachan, 2003: 284). Међутим, демографска структура оружаних снага није одговарала демографској слици међу официрима, које су у готово 90 процената чинили Немци или Мађари, док су у резервном саставу чинили око 85 процената (Bassett, 2016: 458-459; Rothenberg, 1998: 127-128). Слична ситуација била је и у случају подофицира (Strachan, 2005: 282). 
Табела 1. Процентуална заступљеност етничких група у аустроугарској војсци (Strachan, 2003: 282)

\begin{tabular}{|c|c|}
\hline ЕТНИЧКА ГРУПА & ПРОЦЕНАТ ЗАСТУПљЕНОСТИ \\
\hline Немци & $25 \%$ \\
\hline Мађари & $20 \%$ \\
\hline Чеси & $13 \%$ \\
\hline Србо-Хрвати & $9 \%$ \\
\hline Пољаци и Украјинци & $8 \%$ \\
\hline Румуни & $7 \%$ \\
\hline Словаци & $4 \%$ \\
\hline Словенци & $2 \%$ \\
\hline Италијани & $1 \%$ \\
\hline
\end{tabular}

И поред тога што није постојала апсолутна етничка већина у оружаним снагама Аустроугарске, официрски и подофицирски корпус су доминантно чинили Немци, делом и Мађари, што и не чуди с обзиром да је војна елита Аустроугарске била врло искључива према Словенима генерално. (Bassett, 2016: 371). Самим тим, постојао је раздор у војсци између официра и подофицира и војника који су били друге етничке припадности.

\section{Језичка политика у аустроугарској војсци}

Комплексна демографска и етничка структура Аустроугарске, која се рефлектовала и на оружане снаге земље, свакако није била неопажена у вишим војним круговима, па је аустроугарска војска имала политику решавања овог проблема. Подела војске на Царско-краљевску (у даљем тексту Ландвер), Мађарску краљевску војску (у даљем тексту Хонвеg) и Царску и краљевску војску (у даљем тексту Зајеgничка војска), била је резултат компромиса између централизације и аутономије, који се пренео и на језике у употреби у овим оружаним снагама. Према компромису, немачки је остао командни језик (Kommandosprache) у свим јединицама (Bassett, 2016: 367). На нижем нивоу постојао је језик свакодневне службе (Dienstsprache), који је у Хонведу био мађарски, а у Ландверу немачки (Bassett, 2016: 367). Поред тога, пук који није био састављен од Мађара или Немаца користио је, такође, језик војника пука (Regimentsprache) у свакодневној употреби (Bassett, 2016: 367). Одређење језика пука се вршило уколико је барем 20 процената војника говорило тим језиком (Schindler, 2015: 42). 
Према наведеној језичкој политици, могло је бити чак до 5 различитих језика пука, уз немачки као командни језик, а уколико је јединица била у склопу Хонведа још и мађарски. Иако је, на нивоу пука, језик пука био најзначајнији, према Џону Шиндлеру (John R. Schindler) сви војници су морали да знају отприлике 80 фраза командног језика на немачком, као и око хиљаду техничких израза и фраза такође на немачком као део језика свакодневне службе (Schindler, 2015: 41-42). Бројност пуковских језика углавном је зависила од географског седишта одређеног корпуca. Пошто су корпуси били организовани по територијалном принципу (Pernes et al., 2003: 335), етнички хетерогенији региони имали су јединице са већим бројем језика, као што су на пример били Банат или Истра.

Спровођење овакве језичке политике у оквирима сопствених оружаних снага, уз предоминантност Немаца и Мађара на нивоима официра и подофицира, захтевало је две ствари: прво, да војници усвоје одређени број фраза на немачком и да официри науче пуковске језике. За официре је оваква ситуација била знатно неповољнија, јер су морали не само да знају све признате пуковске језике, већ да их науче у року од три године, што би доказали полагањем испита (Schindler, 2015: 42). Са дванаест етничких група које су чиниле минимум један проценат оружаних снага Аустроугарске, оваква процедура захтевала је знатна улагања у развој кадрова које је, у случају губитка, било тешко надоместити.

Желећи да смање бројност језика, вероватно препознајући сличности између словенских језика, али и због чињенице да су отприлике 45 процената укупног броја војника чинили Словени, Аустроугарска је покушала да формира војно-словенски језик, који би сви словенски припадници могли да разумеју (Schindler, 2015: 43). Међутим, иако се не може порећи чињеница да су словенски језици међусобно довољно слични да се основна комуникација може остварити, поготово уз помоћ пантомиме, из перспективе заједничког тактичког деловања постоје проблеми. Они се највише манифестују у чињеници да међу словенским језицима постоје идентичне речи које имају друкчија значења. Можда најједноставнији пример се може пронаћи у поређењу чешког и српског језика. Чешка реч имају различита значења, јер у Чешком фирраво значи gесно. Слично је и у другим западнословенским језицима у односу на јужнословенске. Неразумевање ове базичне речи приликом ангажовања снага у бици могло је произвести катастрофалне тактичке последице, што доводи у питање ефективност војно-словенског језика. 


\section{Утицај језика на тактичку ефективност}

У претходним поглављима приказана је сва комплексност Аустроугарске, како државе, тако и њених оружаних снага. Међутим, свођење на конкретне бројеве још додатно приказује сложеност ситуације. Заједничка војска Аустроугарске имала је 102 пука, од којих је свега 15 имало више од 90 процената припадника једне етничке групе (Schindler, 2015: 42). Међутим, и у тих 15 нису сви пукови били искључиво немачки, као што је пример Двадесетосмог пука, који су у 98 процената чинили Чеси (Lein, 2009: 232). Ситуација је била још комплекснија на батаљонском нивоу, где је већина батаљона имала барем два ако не и више језика (Strachan, 2003, 282). У оквирима 142 јединице које су имале само један пуковски језик, свега 31 је била чисто немачка (Schindler, 2015: 42; Strachan, 2003: 282).

У случајевима јединица попут 129. Пука, који је „садржао 29 процената Немаца, 24 процената Срба, 20 процената Мађара, 20 процената Румуна и 3,5 процената Хрвата и Словака...[односно]...203. пука...[који је садржао]...27,5 процената Хрвата, 20 процената Мађара, 13 процената Срба, 12,5 процената Словака, 7,5 процената Чеха, 6,5 процената Немаца, 5,5, процената Румуна, 3,5 процената Пољака и Русина и 0,5 процената Словенаца“"(Herwig, 2009: 343), зарад адекватне тактичке ефективности њихови официри су морали познавати већину језика наведених етничких група да би успешно комуницирали и координирали тактичке замисли. Слични примери су 5. драгунски пук, где је „пуковски лекар редовно спроводио прегледе на седам различитих језика" (Schindler, 2015: 42), или 61. пук, сачињен од Румуна, Немаца, Мађара и Срба (Schindler, 2015: 42).

У идеалном сценарију овакав систем је још донекле и могао да функционише. Уколико су официри и подофицири одређене јединице говорили разнолике пуковске језике, а војници усвојили кључне фразе командног језика, координација, комуникација и лидерство, као елементи тактичке ефективности су могли да функционишу. Међутим, у стварности таква ситуација се није манифестовала. Ретко која јединица је савладала све фразе командног језика (Herwig, 2009: 142), а пример батаљона Хонведа сачињеног предоминантно од Румуна, у којем ниједан официр није говорио румунски, био је правило а не изузетак (Strachan, 2003: 282). Штавише, чак и уколико бисмо занемарили „стање на терену“ и остали у оквирима идеалног сценарија, само отпочињање рата, које неминовно доводи до жртава, учинило је овакав систем неодрживим. Замена погинулих и повређених официра довела је резервне официре, који нису имали адекватан степен познавања језика пука ком су додељени (Engle, 
2014: 150). Таква ситуација је била у 12. корпусу, који је после великог броја жртава добио нове официре који нису могли да комуницирају са својим румунским војницима (Schindler, 2015: 275).

Зарад остваривања тактичке ефективности јединица, адекватно лидерство њених официра је значајно. Међутим, без способности говорења истог језика, као кључног предуслова за задовољење индикатора лидерства (Brathwaite, 2018: 4), способност усмеравања делања на тактичком нивоу од стране официра је готово немогућа. Примери 129. или 203. пука указују на степен лингвистичких способности које су њихови официри морали поседовати да би задовољили неопходан степен тактичке ефективности и остварили стратегијске замисли. Са друге стране, почивање тоталног рата на масовној мобилизацији упућује и на обавезу сваког војника да не само успешно усвоји фразе командног језика, већ и да их у околностима борбених операција препозна и успешно изврши. Спровођење борбених активности и неопходност замене повређених и погинулих официра новима, само је чинила ситуацију још тежом.

Последице језичке баријере нису се искључиво односиле на однос официра и војника. Тактичка ефективност захтева и степен координације између самих војника. Уколико две одвојене јединице, на тактичком нивоу, нису у стању да сарађују, тактичка ефективност одређене војске опада. Дакле, неопходност комуникације коју језичка баријера онемогућава, не везује се искључиво за вертикални однос официр-војник, већ и за хоризонтални однос између две јединице војника. Током битке на Церу, војници из 21. дивизије су у неколико наврата отворили ватру на војнике 42. дивизије Хонведа, али и на друге јединице у којима су војници говорили српско-хрватски, мешајући их са српским војницима (Schindler, 2002: 169-170). Са друге стране, због страха од пребега, аустроугарска команда је редистрибуирала италијанске и словенске војнике на друге фронтове (Herwig, 2009: 154; Lein, 2009: 231), што је довело до тога да батаљони из Чешке и Тирола заједнички спроводе операције (Lein, 2009: 240). Различити пуковски језици онемогућили су ефективну тактичку координацију делања јединица различитих пукова. Претпоставка координације је комуникација, па без могућности разумевања услед непознавања језика тактичка ефективност садејства јединица различитих језика је ограничена.

На крају, успостављање утицаја језичке баријере искључиво у оквиру скупа вештина као детерминанти тактичке ефективности, иако важније, није једино. Утицаји језичке баријере имали су тенденцију да се прелију и у факторе воље за борбу, са случајевима где нови регрути у 
аустроугарској војсци нису гледали благонаклоно на службу са војницима који говоре други језик (Cornwall, 1997: 178). Тиме, различити језици нису утицали само на вештине војника и официра неопходне за тактичку ефективност, већ и на морал, као одлику воље војника да се боре, што такође чини индикатор тактичке ефективности.

\section{Закључак}

Војна моћ одређене државе није искључиви производ простог збира материјалних и људских ресурса. Војна моћ захтева од државе и да поседује способност да наведене потенцијале искористи, координише и усмери зарад генерисања повољних војних исхода. Без адекватног степена војне ефективности, војни потенцијал се не може превести у војну моћ и тако држава постаје рањива у међународној арени. Уколико се не раде праве ствари, потенцијал остаје само потенцијал. Међуповезаност политике и стратегије, као и међуповезаност стратегијског, оперативног и тактичког нивоа, уз признавање њихових различитости које су и довеле до наведене диверсификације, захтевају постојање ефективности на свим нивоима и њихову заједничку усмереност ка остварењу државних циљева. Постојање прекида у ефективности на било ком нивоу, доводи до губитка свеобухватне војне ефективности.

Случај Аустроугарске представља можда најрепрезентативнији пример последица недостатка војне ефективности. Поред бројних проблема с којима се суочавала Аустроугарска, како уочи тако и током Првог светског рата, недостатак ефективности на најнижем тактичком нивоу, изазван језичким разликама, представљао је кључни (додуше не и једини) разлог њене војне неефективности. Етничка структура Аустроугарске, као најзаступљеније објашњење аустроугарског пораза, имала је утицаја на војну неефективност, и то индиректно, јер су различите етничке групе говориле различитим језицима, проузрокујући тако и немогућност војника да комуницирају како између себе тако и са својим официрима.

Иако је Аустроугарска успоставила комплексан систем језика команде, језика свакодневне употребе и пуковских језика, како би умањила утицај плуралитета језика у својим оружаним снагама, тај систем не само да никада у потпуности није заживео, него се и распао са порастом жртава током самог рата.

Улога језика, тачније познавања истог језика у оквирима једне јединице, представља кључни предуслов за тактичку ефективност те једи- 
нице у остварењу борбених задатака. Без могућности комуникације и координације, као и преношења и разумевања упутстава од стране лидерства јединице, материјални капацитети и поседовање војног потенцијала нису сами по себи довољни за остварење војних циљева, из разлога што се не могу употребити ефективно, то јест на прави начин. Са својом хетерогеном етничком структуром и оружаним снагама које су сачињавали припадници бројних етничких група, чије је познавање немачког било упитно, аустроугарска војска се може узети као добар пример генералнијег питања шта се догађа када је војска сачињена од војника различитих националности који не говоре истим језиком, те отуда нису у могућности да ефикасно и ефективно комуницирају и координирају своје напоре. 


\section{ЛИТЕРАТУРА}

Bassett, R. (2016). For God and Kaiser: The Imperial Austrian Army, 16191918. New Haven: Yale University Press.

Betts, R. K. (2000). Is Strategy an Illusion?. International Security, 25(2), 5-50.

Biddle, S. (2017). Military Effectiveness. Preuzeto 13. jula, 2019., sa https: // oxfordre.com / internationalstudies / view / 10.1093 / acrefore /9780190846626.001.0001 /acrefore-9780190846626-e-35\#acrefore9780190846626-e-35-bibliography-0004

Brathwaite, K. J. H. (2018). Effective in Battle: Conceptualizing soldiers' combat effectiveness. Defence Studies, 18(1), 1-18.

Brooks, R. A. (2007). Introduction: The Impact of Culture, Society, Institutions, and International Forces on Military Effectiveness. In R. A. Brooks and E. A. Stanley (Eds.) (2007). Creating Military Power: The Sources of Military Effectiveness. (pp. 1-26). Stanford: Stanford University Press.

Clauzewitz, C. (2007). On War. Oxford: Oxford University Press.

Cornwall, M. (1997). Morale and patriotism in the Austro-Hungarian army, 1914-1918. In J. Horne (Ed.) (1997). State, society and mobilization in Europe during the First World War. (pp. 173-191). Cambridge: Cambridge University Press.

Dredger, J. A. (2017). Tactics and Procurement in the Habsburg Military, 18661918. London: Palgrave Macmillan.

Drucker, P. F. (2009). Management: Revised Edition. New York: Harper Collins e-books.

Engle, J. (2014). "This monstrous front will devour us all": The AustroHungarian Soldier Experience, 1914-1915. In G. Bischof, F. Karlhofe and R. Williamson Jr (Eds.) (2014). 1914: Austria-Hungary, The Origins, and the First Year of World War I. (pp. 145-166). New Orleans and Innsbruck: New Orleans University Press and Innsbruck University Press.

Hart, L. B. H. (1991). Strategy. New York: Meridian.

Hayward, P. (1968). The Measurement of Combat Effectiveness. Operations Research, 16(2), 314-323.

Herwig, H. H. (2009). The First World War: Germany and Austria-Hungary 1914-1918. London: Bloomsbury Academic.

Jobbagy, Z. (2009). The Efficiency Aspect of Military Effectiveness. Militaire Spectator, 178 (10), 506-514.

Kardum, L and Korea Gajski, B. (2012). Language as a political issue: The case of language of command in the Austro-Hungarian army. Jezikoslovlje, 13 (2), 351-371. 
Kennedy, P. (1988). The Rise and Fall of the Great Powers: Economic Change and Military Conflicts from 1500 to 2000. London: Unwin Hyman.

Lein, R. (2009). „The "Betrayal” of the k.u.k. Infantry Regiment 28 Truth or Legend?". In: A. Suppan and Lein, R. (Eds.) (2009). East European Identities in the $19^{\text {th }}$ and $20^{\text {th }}$ Century. Vienna: LIT Verlag, 231-256.

Luttwak, E. N. (1980-1981). The Operational Level of War. International Security, 5(3), 61-79.

Marshall, S. L. A. (2000). Men against Fire: The Problem of Battle Command. Norman: University of Oklahoma Press.

Millett, A. R., Murray, W. \& Watman, K. H. (1986). The Effectiveness of Military Organizations. International Security, 11(1), 37-71.

Murray, W. and Millett, A. R. (2010). „Introduction: Military Effectiveness Twenty Years After“. In: Murray, W. \& Millett, A. R. (Eds.) (2010). Military Effectiveness Volume 3: The Second World War. New York: Cambridge University Press, xi-xix.

Pernes, J., Dolejší, J., Fučík, J. \& Havel, P. (2003). Pod Cisarskym Praporem: Historie Habsburske Armady 1526-1918. Praha: Nakladatelstvi Elka Press.

Romsics, I. (2002). Dismantling of Historic Hungary: The Peace Treaty of Trianon, 1920. New York: Columbia University Press.

Rothenberg, G. E. (1989). The Austro-Hungarian Campaign Against Serbia in 1914. The Journal of Military History, 53(2), 127-146.

Rothenberg, G. E. (1998). The Army of Francis Joseph. West Lafayette: Purdue University Press.

Schindler, J. R. (2002). Disaster on the Drina: The Austro-Hungarian Army in Serbia, 1914. War in History, 9(2), 159-195.

Schindler, J. R. (2003). Steamrollered in Galicia: The Austro-Hungarian Army and the Brusilov Offensive, 1916. War in History, 10(1), 27-59.

Schindler, J. R. (2015). Fall of the Double Eagle: The Battle for Galicia and the Demise of Austria-Hungary. Lincoln: Potomac Books. Amazon Kindle Edition.

Strachan, H. (2003). First world war: Volume I: To Arms. Oxford: Oxford University Press.

Strachan, H. (2005). European Armies and the Conduct of War. London and New York: Routledge.

Strachan, H. (2008). The lost meaning of strategy. In: Mahnken, T. G. \& Maiolo, J. A. (Eds.) (2008). Strategic Studies: A Reader. New York: Routledge, 421-436.

Strachan, H. (2019). Strategy in theory; strategy in practice. Journal of Strategic Studies, 42(2), 171-190. 
Trevelyan, G. M. (1915). Austria-Hungary and Serbia. The North American Review, 201(715), 860-868.

Бофр, А. (1968). Увод у стратегију. Београд: Војноиздавачки завод.

Каровић, С., Жупац, Г., и Ристић, В. (2011). Војни менаџмент - научна дисциплина наука о менаџменту и бизнису или наука одбране. Војно дело, 63(2), 251-261.

Ковачевић, Н. В., Домјанчић, С., и Ковач, М. П. (2018). Стратегијски менаџмент у војноорганизационим системима. Војно дело, 70(3), 252-283.

Павловић, С. К. (2018). Историја Балкана 1804-1945. Београд: CLIO.

Стефановић, С. и Форца, Б. (2015). Предуслови и неопходне мере за ефикасно и ефективно учешће Војске Србије у мисијама и операцијама заједничке безбедносне и одбрамбене политике ЕУ. Војно дело, 67(3), 222-250.

Сун, Цу. (2015). Умеће ратована. Београд: IndMedia Publishing.

Форца, Б. (2011). Стратешки менаџмент у систему одбране. Војно дело, 63(4), 196-220.

Цвијић, J. (1996). Антропогеографски и етнографски списи II. Београд: Српска академија наука и уметности. 


\title{
LANGUAGE AS AN OBSTACLE TO THE TACTICAL EFFECTIVENESS OF THE AUSTRO-HUNGARIAN ARMY IN THE FIRST WORLD WAR
}

\author{
Mihajlo Kopanja, Research Assistant \\ Institute of International Politics and Economics, Belgrade
}

\begin{abstract}
Summary
There exists a general agreement among authors that the Austro-Hungarian army, during the First World War underperformed far from what its military potential allowed for, and its ambitions demanded. Yet, the predominant reason for the lack of military effectiveness of the Austro-Hungarian army is far from being agreed upon. The goal of this paper is to present an alternative explanation to the ineffectiveness of the Austro-Hungarian army during the First World War by highlighting the plurality of languages among its solders. The main argument of the paper is that the plurality of languages of the soldiers of the Austro-Hungarian army prevented adequate communication and coordination between the soldiers and officers, as well as between soldiers of different nationalities themselves, thus reducing the tactical effectiveness on the battlefield. By analyzing the concept of tactical effectiveness, tactics, and the connection between strategic, operational and tactical levels, as well as Austro-Hungary itself and its army in the wake of the First World War, the paper shows that the complex language policy of Austro-Hungarian army proved inefficient and unsustainable during the war. Thus, adequate communication and cooperation as well as officer leadership, representing the foundations of tactical effectiveness, was disabled and its effects transferred to other levels leading to the defeat of Austro-Hungary.
\end{abstract}

Keywords: tactics, tactical effectiveness, military effectiveness, language, Austro-Hungary. 